\title{
Megali İdea'dan Ankara Antlaşmasına (1930) Eleftherios Venizelos
}

\section{Damla DEMİRÖZய̈*}

\section{ÖZET}

Bu makalede, öncelikle, Türk tarihi açısından önemli olduğunu düşündüğüm Yunanca bir belgeyi okuyucuyla paylaşmak istiyorum. Bu belge, Eleftherios Venizelos'un 30 Ağustos 1928 tarihinde İsmet İnönü'ye göndermek üzere elyazısı ile yazdığı bir mektup. Bu mektupdan hareketle: (a) Venizelos'un Yunan iç politikasında Megali İdea ile yaşadı̆̆ serüvene ve (b) bu serüvenin sonucuna bağll olarak Türkiye konusunda değişiklik gösteren dış politikasına değinilecek.

\section{From Megali Idea To Rapprochement Of Ankara (1930) Eleftherios Venizelos}

\section{Abstract}

This article starts with the presentation of a Greek document that is related directly to Turkish contemporary history. The document is a letter by Venizelos, which he adressed to Ismet Inonu, on 30th of August, 1928. With references to this letter, the article focuses on: (a) acts of Venizelos with Megali Idea in Greek policy and

(b) changes in Venizelos's attitude concerning the 'Eastern Question' after the foundation of Turkish Republic in 1923.

\section{Giriş}

Yunan tarihi ve Yunanistan, kuşkusuz, Osmanlı ve Türk tarihinin önemli parçalarından biri. Buna rağmen, Çağdaş Yunan'a ${ }^{1}$ ait bilgilerin

- Ankara Üniversitesi, Dil ve Tarih-Coğrafya Fakültesi, Batı Dilleri ve Edebiyatları Bölümü Çağdaş Yunan Dili ve Edebiyatı Anabilim Dahı Öğretim Görevlisi.

${ }^{1}$ Yunanistan ve Yunan sözcükleri diğer ülke ve ulus isimlerinin aksine Antik ve Çăgdaş/Modern sözcükleri ile tanımlanan belki de yegane isimlerdir. Antik Yunan'a ait araştırmaların ülkemizde de Batı ülkelerinde olduğu gibi bir geleneği var. Bu yazıda Çağdaş Yunan terimi ile kastedilen 1821 sonrası kurulan Yunan ulus devleti veYunanistan'dır. 
üniversitelerde sistematik bir biçimde öğretilmesi ve araştırılmaya açılması çok yeni. Çağdaş Yunan Dili ve Edebiyatı anabilim dalı olarak ilk, 1991-92 yılında Ankara Üniversitesi'nde ve daha sonra, 2000-2001 y1lında İstanbul Üniversitesi'nde açıldı. Bunların yanı sıra, Boğaziçi Üniversitesi de 1997-98 yılından başlayarak öğrencilerine Çağdaş Yunan Dilini seçmeli ders olarak sunuyor. Ve nihayet özel bir üniversite; Bilgi Üniversitesi, 2005-2006 akademik yılında Türkiye-Yunanistan ağırlıklı özel bir master programı başlattı. $^{2}$

Yukarıda kısaca özetlenen gelişmelere paralel olarak, Türkiye'de Yunanca kaynakların da kullanımı ile yazılan araştırmaların sayısı giderek artıyor. Bu araştırmalar yalnızca Yunan dilinde yazılmış bibliografyayı kapsamakla kalmıyor. Ama aynı zamanda Yunanistan'ın akademik gündeminde var olan tartışmalardan da haberdar.

$\mathrm{Bu}$ makalede, öncelikle, Türk tarihi açısından önemli olduğunu düşündügüum Yunanca bir belgeyi okuyucuyla paylaşmak istiyorum. Bu belge, Eleftherios Venizelos'un 30 Ağustos 1928 tarihinde İsmet İnönü'ye göndermek üzere elyazısı ile yazdığı bir mektup. Bu mektup birkaç açıdan önemli. Yazarı, herhangi bir politikacı değil, siyasi hayatı özellikle 19101935 yılları arasında Yunanistan'ın siyasi hayatı ile içiçe geçmiş olan Venizelos. Aşağıda, Türkçe çevirisi yer alan mektubunda ise Türk-Yunan ilişkilerini nasıl gördüğünü, ne gibi sorunlar tespit ettiğini ve bu iki ülke ilişkileri için nasıl bir gelecek planladığını dile getiriyor.

$\mathrm{Bu}$ makalede, öncelikle, Megali İdea'nın Yunan milliyetçiliği içinde ortaya çıkış sürecine kısaca değinilecek. Daha sonra, Venizelos'un Yunan politikasında Megali İdea ile yaşadığı serüven ve buna bağlı olarak değişen 'Türkiye' politikası hakkında bilgi verilecek.

(a) Venizelos'un 30 Ağustos 1928 tarihli elyazısı mektubunun Türkçe çevirisi: ${ }^{3}$

(Yunanca'dan çeviriyi yaparken asıl kaygım Venizelos'un kullandığı ifadeleri mümkün olduğunca aslına sadık kalarak Türkçe'ye aktarmak oldu. $\mathrm{Bu}$ nedenle, Yunan dilinde siklıkla kullanılan tek ve uzun cümle yapısını, küçük cümleler halinde Türkçe'ye çevirdim. Venizelos'un mektubunda yaptığı düzeltmeleri, yani üstünü çizdiği sözcükleri altlarını çizerek belirttim.)

${ }^{2}$ Elbette aynı durum Yunanistan ve Yunan tarihi için de geçerli. 1821 öncesi ve sonrası Yunan tarihini daha iyi anlayabilmek ancak Osmanlı ve Türk tarihini bilmekle mümkün. Atina Üniversitesi'nde Türk Dili ve Edebiyatı Anabilim Dalı'nın açılması ise ancak 20042005 akademik yılında gerçekleşti.

${ }^{3}$ Bu belgeyi Atina'da bulunan Eleftherios Venizelos ve Dönemi Vakfı Arşivi'nde buldum. Eleftherios Venizelos ve Dönemi Vakfı'nın yöneticisi Dimitris Mihalopoulos'a bu tarihi belgenin fotokopisini çektirmeme izin verdiği teşekkür ederim. Bu fotokopinin bilgisayarda taranmış bir örneği EK I'dedir. 
Bakanlar Kurulu

Başkanı

İsmet Paşa'ya mektup

Rüstü've mektup

Atina, 30 A $\breve{g}$ ustos 1928

Sayın Başkan

\section{Excellence}

Yunan halkının büyük bir çoğunluğu güven göstererek kaderlerini dört yıllığına bana teslim etmiş bulunuyor. Sizi temin etmek isterim ki benim en büyük arzum, iki ülke ilişkilerinin düzenlenmesi ile iki ülke arasında yakın bir dostluğun sağlanması ve bu yakın dostluğu, bu sefer, mümkün olan en geniş şekli ile bir dostluk antlaşması, saldırmazlık ve hakemlik antlaşması ile resmileştirmektir. Türkiye'nin bizim topraklarımızda gözü olmadı̆̆ını iyi bildiğim için seçim süresi boyunca her firsatta halk önünde Yunanistan'ın da Türk topraklarında hiçbir şekilde gözü olmadığını defalarca tekrarladım. Bu konuda var olan antlaşmalar samimiyetle ve kayıtsı-şartsız kabul edilir.

Bugün sayın Rüstü Bey'e yazdı̆̆ım bu özel mektup ile onun da katkıların talep ediyorum.

Lozan'daki işbirliğimiz her ne kadar benim ülkem için talihsiz şartlar altında gerçekleşti ise de bu işbirliğimizin hoş anısını her zaman muhafaza ediyor ve büyük bir ilgi ile Türkiye'de ülkeyi yeniden kuruşunuzu izliyorum. Şundan eminim ki, her iki ülke arasında var olan anlaşmazlığ yeni bir dostluk antlaşması ile bitirirsek sonlandırırsak ve bu antlaşma bir taraf için zafer ile sonuçlanan bir savaş ertesinde yapılmaz, tam tersine her iki tarafin da özgür iradeleri sonucu yapılır ise o zaman daha değerli olur, işte o

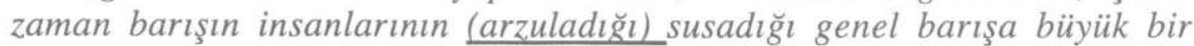
hizmet etmiş oluruz. Hicbir sey bu iki devletin [bu barısa] ulasmasint engelleyemez.. Ekselanslarl, ilişkilerimizin bu şekilde düzenlenmesinin her iki tarafin da ortak arzusu olduğundan kuşku duymuyorum. Bu ortak arzumuzun gerçekleşmesine, nüfus mübadelesinden kaynaklanan ve daha sonra oluşan, her iki ülke için de hayati öneme sahip olan meselelerden başka hiçbir şey engel olmamaktadır. Karşılıklı bir barış antlaşmasını

${ }^{4}$ Yunan dilinde Türkiye ve Türk kelimelerinin kullanımı çok eskidir. 
imzalayacak bu iki ülke pek çok menfaatlerini daha yetkin bir biçimde koruyayabilir. Bu çok değerli hedefimizin gerçekleşmesi için çok değerli katkılarını esirgemeyeceğini düşündü̈̆ü̈m Rüstü Bey'e de (ona) yazıyorum.

Bay Başkan bu teminatıma lütfen inanınız, siz ekselanslarının görüsleri benim için cok değerlidir, saygllarımla.

Venizelos bu mektubu 30 Ağustos 1928 tarihinde, yani 19 Ağustos 1928 seçimlerini kazandıktan onbir gün sonra yazıyor. Venizelos'un seçimleri kazanmasının hemen ardından böyle bir mektubu kaleme alması onun hem Türk-Yunan ilişkilerini verdiği öneme hem de dört yıllık iktidarında nasıl bir dışpolitika izleyeceğine dair ipuçları veriyor. Bu mektubun Venizelos'un elyazısı ile yazılmış olması ve yaptığı düzeltmeleri üzerinde taşıması ise tarihi bir belge olarak mektubun değerini daha da artırıyor. Böylece resmi bir el tarafından düzeltilmemiş ifadelerin yanı sıra yapılan küçük değişiklikleri de okumak mümkün. ${ }^{5}$

Mektubu dikkatle okuduğumuzda Venizelos'un Türk-Yunan ilişkileri konusunda şu tespitlerde bulunduğunu görüyoruz: (a) geçmişte toprak talebiyle yaşanan sorunlar her iki ülke açısından da tarih olmuştur. Bu sözler Venizelos'un Megali İdea ile olan geçmişi ve 1919'da Anadolu'ya çıkanın Yunan ordusu olduğu düşünüldüğünde özellikle tepki uyandıracak niteliktedir. Venizelos'un Türkiye'nin Yunanistan'dan toprak talebine dair sözleri daha çok Yunan kamuoyuna, yani 'iç tüketime' yöneliktir. Ayrıca, Yunan resmi tarih yazıcılığı ve milli söyleminin Osmanlı'yı ya da 'Turkokratia'yı ${ }^{6}$ nasıl algıladığını ve yorumladığını bilmek Venizelos'un bu sözleri neden söylediğini anlamamızı kolaylaştıracaktır. Milliyetçi anlayış içinde yorumlanan Yunan tarihi ve söylemine göre 'Turkokratia' bir imparatorluk olarak değildir, Yunan topraklarını işgal etmiş yabancı bir egemenlik 'öteki'nin egemenliğidir. Dolayısı ile Venizelos 'toprak talebi ’ile çıkan sorunların iki taraf için de bittiğini söylerken gönderme yaptığı husus

${ }^{5}$ Yakın dönem Türk-Yunan tarihini inceleyen ender kitaplardan biri olan Enis Tulça'nın, Atatürk, Venizelos ve Bir Diplomat Enis Bey (Simurg, İstanbul: 2005) adlı kitabında söz konusu mektup taslağının yalnızca küçük bir paragrafının çevirisini buluyoruz. Bu çeviri şöyle:

"Sayın Baskan.

Yunan milleti bugün bana dört yıllık bir hükümet etme vazifesi vermiştir. Bu süre içinde ülkelerimiz arasındaki meseleleri bir dostluk, hakem ve saldırmazlık anlaşmast çerçevesinde en iyi sekilde çözebilmek arzumu size bildrimek isterim. Türkiye'nin topraklarımızla hiçbir şekilde ilgilenmediğini biliyorum. Ben de seçim beyanlarımda halkıma Yunanistan'ın Türk topraklarında gözü olmasının ülkeye hiçbir menfaat getirmeyeceğini hep söyledim. Yunanistan kosulsuz olarak barts antlasmaların samimiyetle kabul edecektir...." (2005:16). Araştırmacı, telgrafın T.C. Atina Büyükelçiliği Arşivi, sene 1928, dosya 1'de bulunduğunu not ediyor.

${ }^{6}$ Yunan dilinde Osmanlı İmparatorluğu yerine 'Turkokratia' terimi de kullanılır. Kelime Türk Egemenliği anlamına gelir. Turkokratia kelimesinin daha çok muhafazakar kesimin tercih ettiği bir kelime olduğunu söylemek yanlış olmaz. 
başkadır. Zaten Yunanlı siyasetçinin önemle vurguladığı ikinci husus da; (b) Türkiye'de yeni bir ülkenin kurulmasıdır. Mektuptan da anlaşılacağı üzere bizzat kendisi Türkiye Cumhuriyeti'nin Lozan'da kurulușunu ve uluslararası alanda tanınışını kabul eden Yunan heyetinin başındadır. Kısacası Venizelos, Türkiye'de yepyeni bir dönemin başladığının farkındadır. (c) Bu yeni dönemin Yunanistan açısından en önemli sorunu ise kendisinin de Lozan Konferansı sırasında 30 Ocak 1923 tarihinde imzaladığı resmi adı ile "Yunan ve Türk Halklarının Mübadelesine İlişkin Sözleşme ve Protokol" yani Nüfus Mübadelesi'nden kaynaklanmaktadır. (d) Her iki ülkenin de birbirinden toprak talep etmemesi yapılacak bir barışı daha da kolaylaştırmaktadır. Toprak talebinin olmamasına yapılan bu şiddetli vurgu bize asıl sorunun toprağın bölüşülmesi olduğunu açıkça gösteriyor. Her iki ülke de birbirlerinin toprak bütünlüğüne saygı gösterdikleri takdirde bütün diğer meseleler ikincil ve çözülmesi mümkün sorunlardır.

Nitekim, Venizelos bu mektupundan iki y1l sonra Ankara'y1 ziyaret etmiş ve 30 Ekim 1930 tarihinde Ankara Antlaşmasını ya da resmi adı ile (1)Dostluk, Tarafsızlık, Uzlaşma ve Hakemlik Antlaşmasını, (2)Deniz Kuvvetlerinin Sınırlandırılmasına İlişkin Protoklü ve (3)İkamet, Ticaret ve Seyrisefain Antlaşmasını imzalamıştır. Ankara Antlaşması ile özellikle donanma harcamalarının kısılması, yani silahlanma masraflarının her iki ülke için en aza indirilmesi ve iki ülke arasında yapılacak ticari işbirliğinin artması için gerekli yasal çerçeve hazırlanmıştır. Zaten bu antlaşmadan kısa bir süre sonra, 1931 yılında Venizelos Mustafa Kemal Atatürk'ü Nobel Barış Ödülü’ne aday gösterecektir (bk. EKII ).?

1928 yılında İsmet İnönü'ye mektup yazan, Ankara'ya kadar gelerek 1930 Ankara Antlaşmasını imzalayan ve Mustafa Kemal Atatürk'ü Nobel Barış Antlaşması'na aday gösteren Venizelos ile I. Dünya Savaşı öncesinden başlayarak Megali İdea'nın gerçekleşmesi için uğraş veren Venizelos aynı politikacı mıdır? Venizelos'un Megali İdea ile Yunanistan sınırları içinde ve dışında yaşadığı serüven Venizelos'un dış politikasında, 'Türkiye'ye' bakışında değişikliklere sebep olmuş mudur? Aşağıda bu soruya cevap aranacak ve belki ilk defa Yunan tarihi ve milliyetçi hareketi içinde Megali İdea'nın ne demek olduğuna, nasıl olgunlaştığına, milliyetçi bir söylemden gerçek bir hareket haline gelirken geçirdiği aşamalara, hem Venizelos'un hem de Yunan halkının Megali İdea ile olan serüvenine değinilecektir.

${ }^{7}$ M. Kemal Atatürk bu mektupla Nobel Barış Ödülüne aday gösterildiği için ve Venizelos'un Osmanlı İmparatorluğu'nu ve Türkiye'yi nasıl gördüğüne dair bilgiler bulundurduğu için bu mektubun tarafımdan Türkçe'ye yapılan çevirisi EKII'de verilmiştir. 


\section{I-Megali İdea'dan Ankara Antlaşmasına Eleftherios Venizelos}

Megali İdea ve Venizelos: Megali İdea terimini Türkçe'ye Büyük Mefkure ya da Büyük Ülkü olarak çevirmek mümkün. Dilbilim uzmanı Yeorgios Babiniyotis tarafından hazırlanan Çăgdaş Yunanca Sözlük'te Megali İdea teriminin karşısında şu açıklamayı buluyoruz: "Megali İdea Yunan dünyasının üzerinde 19.yy'ın yarısından 20.yy'ın ilk 30 yilına kadar etkili olmuştur. Fikir ('idea') köle durumda olan bütün Yunanlıları kurtarmak ve başkenti İstanbul olan büyük bir Yunan devleti yaratmak idi." (Babinyotis, 1998:1068).

Pek çok araştırmacıya göre Megali İdea (Büyük Mefkure) Yunanistan'da resmi düzeyde ilk defa 1844 yılında yapilan ilk anayasa çalışmaları sırasında, daha sonra başbakan olacak Yoannis Koletti tarafından dile getirilmiştir. Koletti bir hayli uzun ve bugün bizler tarafından muğlak olarak nitelendirilebilecek konuşmasında şunları söyler: "Yunanistan'ın özgürlüğü için herşeyimizi hatta hayatımızı ortaya koyarak yemin ettiğimiz ve özgürlü̆̆̈̈müzü kazandığımız o günü hatırlayınca dehşet içinde kallyorum. Bugün, bu yemini etmiş olan pekçok kişi hala hayatta. Bu yeminin ă̆ırlığını içinde bulunduğumuz şu ortamda da hissetmeliyiz. Burada anayasayı oluşturmak üzere toplandık. Siyasi hayatımızın İncili olan Anayasa bizim varlığımızı haber verir: dinimizi ve politik olarak var oluşumuzu. Yunanistan coğrafi olarak Avrupa'nın merkezindedir. Să̆ında Anadolu/Doğu solunda ise Batl vardır. Bu konumu itibart ile batarken Batı'yl, yeniden doğarken ise Anadolu'y aydınlatmakla yükümlüdür. Bu görevlerden ilkini bizim atalarımız yerine getirdi. İkincisinin gerçekleşmesi ise bizi beklemektedir. Bu yeminin ve bu Büyük Mefkure'nin (Megali İdea) ruhunu gören, milletin en ileri gelen kişileri yalnız Yunanistan'ın kaderi hakkında değil aynı zamanda da Yunan ırkının geleceği hakkında da karar verecek. Keşke silahları ile ne kadar şanlı olduklarını kanıtlamış ve bir önceki Millet Meclisi'nde yerlerini almış olan Germanoslar, Zaimoslar, Kolokotronisler ${ }^{8}$ de bugün burada, aramızda olsa idi. Bu kahramanlar şimdi, benim aracılığım ile o büyük ülke mefkuresinden nasıl uzaklaştığımızı dile getiriyor. $O$ büyük ülke ki ilk defa Rigas'ın şiirinde dile getirilmişti. $O$ zamanlar tek tek yek bir vücut oluşturmuş bütün Yunanlılar bu amacın bir parçasını gerçekleştirmiştik...

Siz de kuşkusuz bu düşüncedesiniz, arzularınız bu yönde, içimizdeki herbir kişi Yunan kökenliliğin bu şanl fikrine sahip. Atina'da Millet Meclisi'nin yaptı ̆̆ toplantıya katılan herkes bu Meclis'in şanına, büyüklüğüne ve taleplerine hayran kaldl ve hayran kaltyor. Atina ve pek çok kent devletten oluşan Yunanistan battl ve batarken etrafint aydınlattı. Bugün yeniden doğan, tek bir amacl, tek bir gücü, tek bir dini ve nihayetinde şu an üzerinde çalıştığımız bir anayasası olan Yunanistan batan Yunanistan'ın sahip olduğu ufka sahip mi acaba...," (Dimaras, 1982:405-406).

\footnotetext{
${ }^{8}$ Yazar, Yunan Devrim kahramanlarının adlarını çoğul halde kullanıyor.
} 
Konuşmanın da gösterdiği gibi dönemin Yunan milliyetçilerine göre Yunanistan'ın kurulması, ${ }^{9}$ yani genişlemesi henüz bitmemiştir. 1821'de Mora yarımadasında kurulan Yunan devletinin sınırları, 1881 yılında zengin Theselya bölgesinin sınırlarına dahil olması, Balkan Savaşları ile Kuzey sınırlarının genişlemesi, büyük ve zengin bir ticaret kenti olan Selanik, Makedonya ile Ege adalarının (Sakız, Midilli ve Sisam), Dedeağaç (Aleksandropolis) ve dahası Girit'in katılması (1913) ile iyice büyümüștür: "Balkan Savaşlarından sonra elde edilen toprak alanı 432.000 hektarl bulmuştu." (Svoronos, 1998:92).

Yunanistan'ın ulus devlet olarak yaşadığı bu genişleme Yunan diline de yansımıştır. Artık, bir yanda 'Eski Yunanistan' (Palea Ellada) vardır diğer yanda ise ülkeye katılan 'Yeni Topraklar' (Nees Hores). 'Yeni Topraklar'daki nüfus ise bir ulus devletin öngördügüu homojenlikten çok uzaktır. ${ }^{10}$

$\mathrm{Bu}$ genişleme zincirindeki tek istsina 1897 yılında yaşanan Girit ayaklanması sonrası Yunan Devleti'nin Osmanlı İmparatorluğu karşısında aldığı yenilgidir. 1897 yenilgisi hakkında yazılan Yunanca makalelerin çoğunda bu yenilgiyi açıklama, hatta mazur gösterme çabası sezilir. ${ }^{11}$ Öte yandan, gayet ironik bir biçimde, 1897 yenilgisi Megali İdea'yı romantik bir hayal, söylem olmaktan çıkararak bir politika haline getirecek Venizelos'un Yunan politkasındaki yerini, bir bakıma, hazırlayacaktır.

${ }^{9}$ Yunanistan, pek çok ayaklanmanın ardından, Mora'da başlayan, bugün Yunan Devrimi olarak adlandırılan 1821 isyanı/ayaklanması sonrası Osmanlı İmparatoluğu'ndan ayrılmıs ve ulus devlet olarak kurulmuștur. 22 Ocak-3 Subat $1830^{\circ}$ da toplanan dönemin büyük güçleri; Fransa, Büyük Britanya ve Rusya Londra Protokolü ile Yunanistan`ın bağımsızlığını tanımış ve yönetim sistemini Krallık olarak belirlemişlerdir. Aynı Büyük Gücler 27 Mart-8 Nisan arasında Babıali ye yaptıkları ziyaretle kendilerinin 3 Subat Londra Protokolü ile Yunanistan`ı tanıdıkları hususunda Osmanlı imparatorluğunu haberdar etmiş, Osmanlı imparatorluğunun da Yunanistan` ın bağımsızlığını tanımasını sağlamışlardır. Katolik Othon yeni kurulan Yunanistan'a Kral olarak atanmıștır.

${ }^{10}$ Burada gözden kaçmaması gereken önemli bir nokta, Yunanistan'a katılan yeni toprakların büyüklüğüne karşın nüfusunda barındırdığı çeşitliliktir: " 'Yeni' Yunanistan'ın topraklarl, ülkenin yüzölçümünü \%70 oranında büyüttü, diğer yandan ülkenin yaklaşık 2.800 .000 olan nüfusu 4.800.000'e çıktı. Ne var ki, yeni katılan yurttaşların tümünün Yunanlt olmadığı kesindi. Örneğin Selanik'teki en kalabalık topluluğu 1492 yılında İspanya'dan sürülen Yahudilerin torunlarl olan ve İspanyolca konuşmayı sürdüren Sefardim Yahudileriydi. Yunanlılara kurtartcı diye bakmak bir yana, Yahudiler kentteki zengin ticari kaynakların denetiminde onları kendilerine rakip olarak görüyorlardı. Yeni ele geçirilen diğer topraklarda bir tür Romence konuşan önemli sayıda Islav, (çoğu Türk olan) Müslüman ve Ulah yaşıyordu. En sorunsuz dönemlerde bile yeni kazanilan bu toprakların karmașık etnik nüfusu bir arada tutmast sorun yaratırdl, nitekim durum, Yunanistan acısından Birinci Dünya Savaşı'nın doğurduğu sonuçlarla daha da çetrefilleşecekti." (Clogg, 1997:107). Açıkça belli olduğu gibi "Yeni Topraklar" da yaşayan nüfusun demografik yapısı bir ulus devletin öngördüğü 'homojenliği' taşımaktan çok uzaktır.

11 Araştırmacı Alekis Politis'e göre 1897 yenilgisi yalnızca bir askeri yenilgi olarak değil Modernleşmeye ve Batılılaşmaya çalışan Yunan Devleti'nin Modernleşmesinin ve Batılılasmasının başarıya ulaşamaması ve bu çabalarının sonuç getirememesi olarak algılandığı için askeri bir yenilginin yaratabileceğinden daha büyük bir hayal kırıklığı yaratmıştır. Daha fazla bilgi için Bk. Aleksis Politis, (1978). Ta Romantika Hronia, Theoria kai Meletes İstorias 14, E.M.N.E. Mnimon, Athina. 
Osmanlı İmparatorluğu karşısında alınan 1897 yenilgisi, Girit'te yaşanan çeşitli ayaklanmaların ${ }^{12}$ sonuçsuz kalması Yunanistan'da saraya, Kral George'a ve dönemin politikacılarına karşı olan hoşnutsuzluğun iyice artmasına sebep olmuștur. Bu hoșnutsuzluğa Balkanlar'da yaşanan siyasi gelişmelerin, ${ }^{13}$ daha da önemlisi 1908 yılında Osmanlı İmparatorluğu'nda yaşanan Jön Türk hareketinin Yunanistan'a ulaşan etkilerinin eklenmesi ile bazı ordu mensupları siyasal hayata müdahale etmiş, 27 Ağustos 1909 Gudi Darbesi' ni $^{14}$ yapmışlardır. İktidardaki Ralli Hükümeti devrilmiştir.

Darbeyi yapan askerler için iktidarı geçmişteki isim ve partilere teslim etmek mümkün değildir. Yunan politikası için yeni bir isim gereklidir $\mathrm{Bu}$ yeni isim o tarihe kadar anakara Yunanistan'ındaki politik yaşamdan uzak, kendini doğum yeri olan Girit'te başarılı bir politikacı olarak ispatlamış olan Eleftherios Venizelos'dur. ${ }^{15} 1910$ yılının Aralık ayında yapılan seçimlerde 22 Ağustos 1910 tarihinde yeni kurulan Fileleftheri partisi büyük bir çoğunlukla (362 sandayeden 300'ünü alarak) seçimi kazanır. Venizelos da Girit'ten Atina'ya gelerek başbakanlık görevini üstlenir.

\footnotetext{
${ }^{12}$ Bu ayaklanmalardan en başlıcaları olarak şunları sayabiliriz: 1896, 1897, 1890, 1905 , 1908: Girit hükümeti tek taraflı olarak adanın Yunanistan'a bağlandığını ilan etti.

${ }^{13}$ Bulgaristan'ın bağımsızlığını ilan etmesi, Bosna-Hersek'in Avusturya-Macaristan'a katılması vb.

${ }_{14}^{14}$ Adını yapıldığı yerin isminden alır.

${ }^{15} 1908$ 'de Girit tek yanlı olarak Yunanistan'a katıldığını ilan ettiğinde Venizelos Girit'in uluslarası ilişkilerinden sorumlu beş kişilik Yürütme Kurulu/komisyonu üyesinden biri olmuştu.
} 


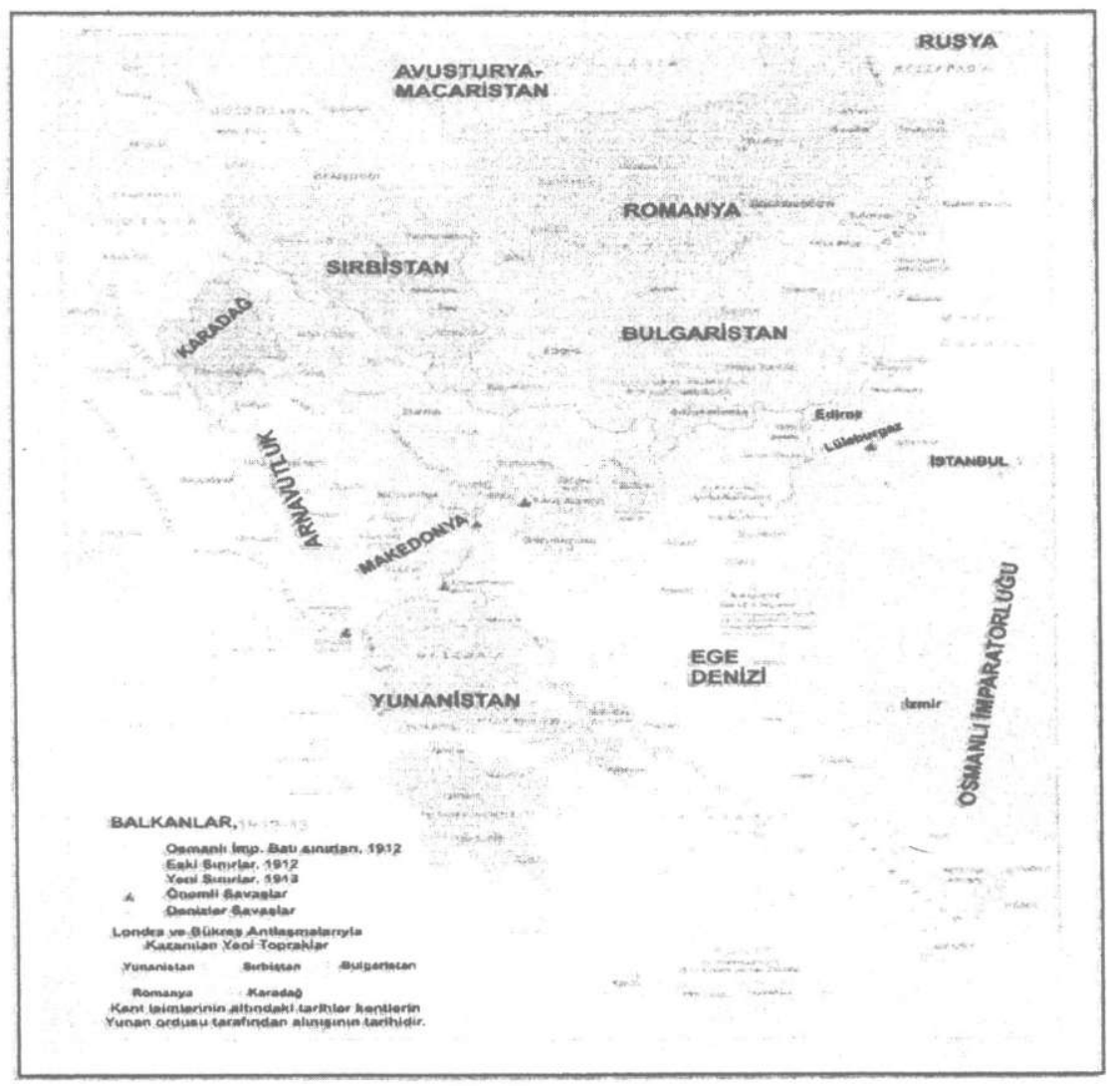

Venizelos, Goudi Darbesi öncesi dönemle bir kan davası gütmez. Uzlaşmacı bir politika izler: Kraliyet ailesinin statüsüne dokunmaz. Yunanistan'1 modernleştirecek reformları hayata geçirir. ${ }^{16}$ Venizelos yönetimindeki Yunanistan asıl atılımını Balkan Savaşları sırasında yapar. Balkan Savaşları ile Yunanistan'ın hem yüzölçümü hem de nüfusu iki katına çıkar. Öyle ki “1913 yazında Yunanistan Akdeniz'de önemli bir güç olarak kendini gösterdi. O güne kadar kaypak bir kavram olan 'Megali İdea' Venizelos'un etkili önderliği altında romantik milliyetçilerin safsataları olmaktan çıkıp olabilirlik sınıfina girmiş görünüyordu." (Clogg, 1997:108).

${ }^{16}$ Theselya'daki büyük çiftlik sahiplerinin topraklarını çıkardığı yasalarla kamulaştırdı, eğitimi çağdaşlaştırdı, kadınlar ve çocuklara asgari ücret verdi, yasadışı işveren sendikalarını yasakladı, işçi sendikalarını yasallaştırdı. 


\section{Ia-Megali İdea mı yoksa 'Küçük Fakat Saygın Yunanistan'mı?}

Bugün Megali İdea hakkındaki genel kanı 1919'da Yunan ordusunun Anadolu'ya çıkması ile sonlanacak Megali İdea'nın bütün Yunanlılar tarafından desteklendiği yönündedir. Oysa Venizelos'un Megali İdea'y1 hayata geçirme düşüncesi Yunanistan'da kolay kabul görmemiştir. Tam tersine ülkede Megali İdea nedeniyle yapılan politik tartışmalar Milli Bölünme'nin (Ethnikos Dihasmos'un) temellerini atmıştır. Milli Bölünme Yunanistan'1 yalnızca I. Dünya Savaşı'nın başlarında değil, Anadolu'da savaştığı 1919-1922 sürecinde, II. Dünya Savaşı'nda ve hemen ardından yaşanacak İç Savaş sürecinde de derinden etkileyecektir. Şimdi I. Dünya Savaşı öncesi Venizelos ile Kral arasında Megali İdea nedeniyle yaşanan görüş ayrılığının ülkeyi nasıl etkilediğine bakalım.

I. Dünya Savaşı öncesi Venizelos için Megali İdea gerçekleştirilmesi mümkün bir politikadır. Osmanlı'yı paylaşmak isteyen İtilaf güçleri için Yunanistan'ın coğrafik konumu stratejik açıdan önemlidir. Bu stratejik önem sınırlarını büyütmek 'Megali İdea'yı gerçekleștirmek isteyen Venizelos için kullanılabilir bir kozdur. Bu sayede Yunanistan da diğer devletlerin yanı sıra Osmanlı İmparatorluğu'ndan toprak alabilecek, Megali İdea gerçekleşebilecektir. ${ }^{17}$ Venizelos Yunan İtilaf Devletlerinden yana savașa girdiğinde sınırların büyüyeceğinden o kadar emindir ki henüz Yunanistan sınırlarına katılmış olan Kavala, Drama ve Serez bölgelerinin Bulgaristan’a bırakılması önerisine bile olumlu bakar.

Kral ise Venizelos'un aksine savaşa katılmamay $1^{18}$ daha uygun buluyor "Küçük Fakat Saygın Yunanistan" fikrini savunuyordu. Albay Metaksas'ın"19 Yunanistan I. Dünya Savaşına girdiği takdirde Bulgaristan'ın durumdan yararlanabileceği düşüncesi ile görevden ayrılması Kral Konstantin'i Yunanistan'ın I. Dünya Savaşı'na savaşa katılması konusunda daha da çekimser yaptı. Bu nedenle, I. Dünya Savașı'nın çıkıșı ile Venizelos ile Kral Konstantinos arasında ciddi fikir ayrılıkları da başgösterdi. Bu bölünme Yunan toplumuna da yansıdı ve 'Milli Bölünme' (Ethnikos Dihasmos) olarak adlandırılacak kamplaşmalara neden oldu.

Kısacası, I. Dünya Savaşı öncesi Megali İdea ne Yunan politikacılarının ne de Yunan halkının üzerinde uzlaştığı ortak bir fikir idi. Bir yanda, Megali İdea'nın gerçekleşmesini isteyen Venizelos vardı. Diğer yanda ise 'Küçük Fakat Saygın Yunanistan' fikrini savunan Kral Konstantin. Bu iki lider (Venizelos ile Kral Konstantinos) arasındaki 'Megali İdea' mı yoksa 'Küçük Fakat Saygın Yunanistan' mı tartışması Yunan halkını da ikiye böldü.

${ }^{17}$ İtilaf Devletleri ile Venizelos arasında Küçük Asya için yapılan pazarlık, İtilaf Devletleri'nin Yunanistan'a verdiği sözler başlıbaşına, ayrı bir araştırma konusudur.

${ }_{18}$ Yunanistan'da pek çok tarihçi Kral'ın bu siyasi tercihini Kral'ın Almanya'ya olan yakınlığı ya da Alman ordusuna duyduğu hayranlıkla açıklar. Kral'ın Almanlara duyduğu yakınlık ya da hayranlığın Kralın I. Dünya Savaşına savaşa katılmama politikasındaki tek etmen olduğunu söylemek ise belki biraz abartılı olur.

${ }^{19}$ I. Dünya Savaşı'ndaki bu çıkışla kendini belli eden albay Yoannis Metaksas 1936 yılında yaptığı Darbe ile ülkeyi II. Dünya Savaşı başlarına kadar diktatörlükle yönetmiştir. 
Megali İdea mı yoksa 'Küçük Fakat Saygın Yunanistan' mı tartışmasının uzayıp gitmesiyle Venizelos 6 Mart 1915'te Başbakanlık görevinden ayrıldı, doğum yeri Girit'e geri döndü. Kral Konstantinos'un Venizelos yerine bağımsız milletvekili Gunaris'i Başbakan yapması, Gunaris'in uzlaşmaz tavırları ise Milli Bölünme'yi daha da güçlendirdi. Meclis 18 Nisan 1915 tarihinde dağıldı. 31 Mayıs 1915 tarihinde ise yeni seçimler yapıldı. 31 Mayıs seçimleri yalnız bir başbakanı seçmiyor ama aynı zamanda da Yunanistan I. Dünya Savaşında yer almalı, Osmanlı'ya karşı savaşa girmeli mi sorusuna da cevap arıyordu. Venizelos ve partisi (Fileleutheri) Yeni Topraklar'daki Yunan olmayan ${ }^{20}$ oyları alamamalarına rağmen 316 sandalyenin 186'sını kazandılar.

Seçimi kazanan Venizelos olmasına rağmen Kral Konstantinos ile arasındaki gergin ilişki, nedeniyle iki kez görevinden ayrıldı. Bu sürece itilaf devletlerinin Pire'ye ve Atina'ya çıkarma yapması (1916 Aralık), Venizelos'un Atina hükümetine karşı 'Yeni Topraklar'ın başkenti Selanik'te kurduğu hükümet ve iki hükümet arasında yaşanan çatışmalar damgasını vurdu. Hem itilaf güçlerinin hem de Venizelos'u destekleyen yurttaşların baskılarına maruz kalan, Anayasanın gereklerini yerine getirememek yani ülkeyi koruyamamakla suçlanan Kral Konstantin 1917 yılının Haziran ayında hiçbir açıklama yapmaksızın ülkeden ayrıldı. Yerine ikinci oğlu Aleksander geçti. Venizelos Atina'ya geri döndü ve hemen ülkesinin İtilaf Güçlerine bağlılığını ve İzmir bölgesine olan ilgisini dile getirmeye başladı. 1915 seçimlerini kazanan Parlemanto'yu toplayarak yeniden iktidara kavuştu. Kral Konstantin yanlısı devlet memurlarını ve ordu mensuplarını tasfiye etti. İtilaf Güçlerine bağlılığını göstermek için Makedonya cephesine asker gönderdi. Antalya'ya çıkan İtalyan askerlerinin İzmir yönünde ilerleyişi nedeniyle İngiltere, Fransa ve Amerika Yunan ordularının İzmir'e

${ }^{20} \mathrm{Bu}$ konudaki bir diğer kayda değer bilgi ise şöyle: "Balkan Savaşlart sonrast Yeni toprakların Yunanistan'a kattlışı nedeniyle bu bölgede yaşamaya devam eden Müslümanlara Yunan uyruğu verilmiştir. Böylece Makdeonya, İpiros, Girit ve Kuzey Ege'de bulunan Midilli, Sakız ve Limni Adası'nda yașayan 560.000'den fazla Müslüman Yunanistan yurttaș olmuştur. 1912 yılında önemli sayıda Müslüman nüfusu olan bölgeler şöyle idi: Kaylar/Ptolemaida (\%93), Drama (\%79), Kavala (\%69), Pravi (\%60), Langada (\%60), Serez (\%40), Yienitsta (\%39), Kastoria (\%24), Kozan (\%40), Selanik (\%26), Kilkis (\%66), Igumenitsa (\%42), Edesa (\%48), Florina (\%32), Verya (\%20) ve Girit (\%20). ${ }^{20}$ Burada yaşayan Müslüman cemaatler birbirleri ile dayanısma halindeydi ve din ortak noktaların oluşturuyordu. Dillerindeki farklılık farklı etnik kimlikleri görünür hale getirse de aralarındaki din bağını zayıflatmıyordu. Din öncelikle Türkçe ikincil olarak ise Arnavutça konusan Müslümanlar arasında milli bilincin olusmasında etkin bir yapı tasını/ortak payda/unsuru/ oluşturuyordu. Makedonya ve Ege Adalarında yaşayan Müslümanların anadili genellikle Türkçe idi. Girit Müslümanları ise Yunanca konuşuyordu. Ipiros'da ise Müslümanlar Arnavutça ve Yunanca konusuyorlardı. Bunlara ek olarak Batı Makedonya'da Yunanca konuşan Müslümanlar, Doğu Makedonya'da Bulgarca konuşan Müslümanlar ve Orta Makedonya'da ise Vlahça konuşan Müslümanlar vardl. Kuzey Yunanistan'da yer yer Arnavutça, Slavca ve Cingenece konusan Müslümanları da bulmak mümkündür. Son olarak, çok sayıda İspanyolca konuşan Müslüman (dönme) Selanik'te kaldı. Böylece Yunan yönetimi yepyeni bir durumla karșı karșıya kalmıștl: Kuzey Yunanistan nüfusunun \%39'unu Müslümanlar oluşturuyordu." (Tsitselikis, 2005:344-345). Yeniden Kurulan Yaşamlar, 1923 Türk-Yunan Zorunlu Nüfus Mübadelesi, (Derleyen, Müfide Pekin) İstanbul Bilgi Üniversitesi Yayınları, İstanbul: 2005. 
çıkmasına karar verdi. Venizelos'un isteği olmuştu. 15 Mayıs 1919'da Yunan donanması İzmir'i kuşattı. ${ }^{21}$

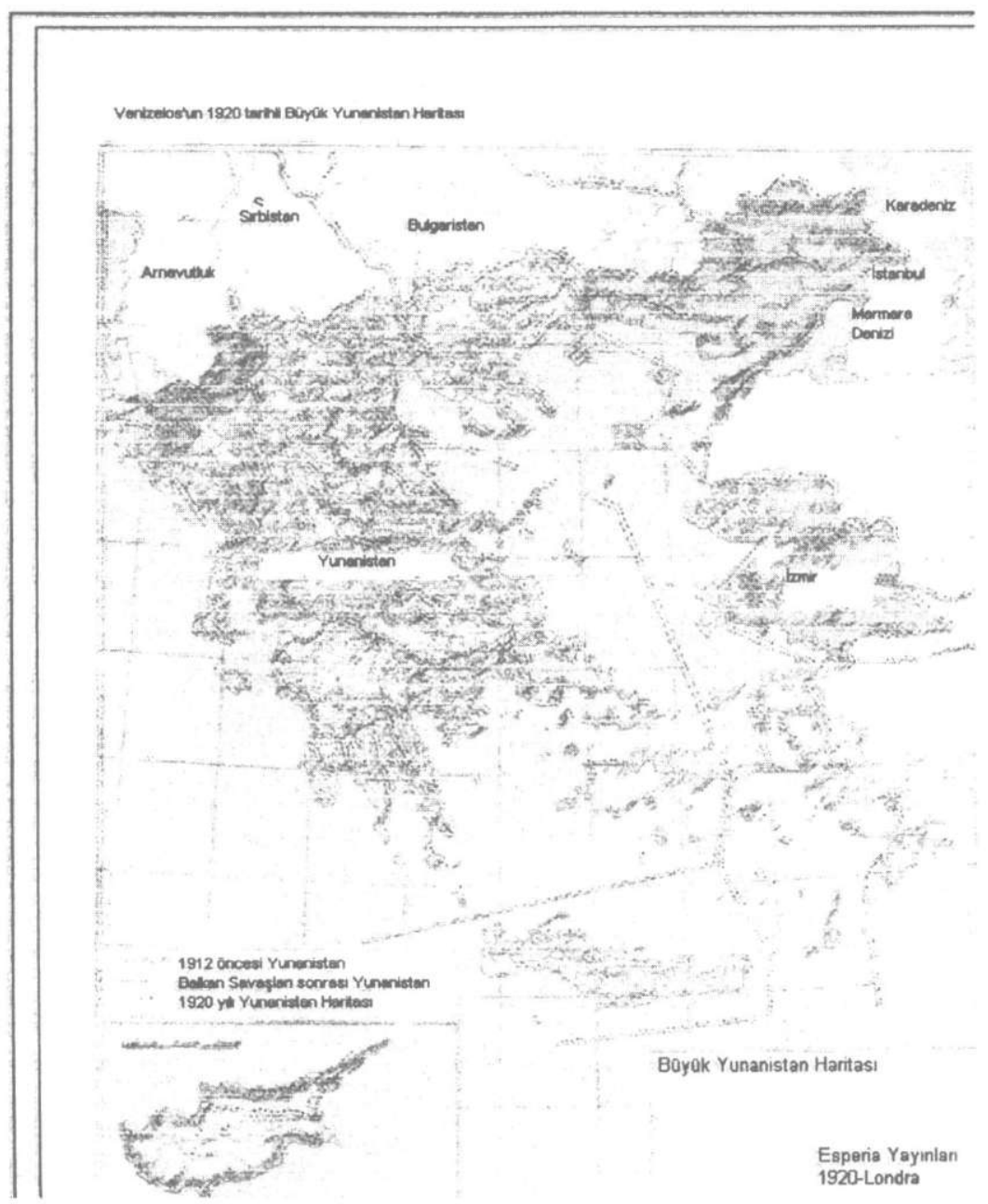

${ }^{21}$ Yunanlı tarihçi Pallis Venizelos'un Megali İdea ve İtilaf Devletleri konusunda izlediği politika hakkında şu ilginç yorumu yapıyor: "Sonunda elde edeceği menfaatler söz konusu olmaksızın bile, Yunanistan'ın itilaf Devletleri yanında savaşa katılmasının büyük yararları olduğuna inanmıștı Venizelos. Belki haklıydı da bu görüsünde. Onun görüșüne göre, Yunanistan'ın iki geleneksel düşmanindan biri olan Türkler' $e^{21}$ (o strada Bulgaristan henüz tarafsızdı ve İtilaf Devletleri tarafindan kendi saflarına çekilmeye çalışlllyordu) öldürücü bir darbe vurma firsatı ortaya çımıstı. Balkan savaslarından beri Türkiye' nin davranıst, Yunanistan'ın Ege Denizi'nde bir donanma kurup Ege adalarının güvenliğini garanti altına almasını engeller bir biçimdeydi. Bu yüzden bir silahlanma yarışı başlamış ve Yunanistan, daha kücük ve fakir olusu sebepiyle gittikce geri kalan bir duruma düssmüstü. Bu bakımdan Avrupa'nın en kuvvetli ü̧̧ devletiyle işbirliği yapabilmek imkanı kolay kaçırılabilecek gibi değildi." (1995: 44). 


\section{Ib-Megali İdea'nın Yenilgileri}

1 Kasım 1920 seçimleri yaklaşırken Venizelos diplomatik başarıları, o tarihe kadar Anadolu'da ilerleyen Yunan ordusunun kazandığı başarılar ve 10 Ağustos 1920 tarihinde imzalanan Sevr Antlașması'nın kendisini seçimlerin tartışmasız galibi yapacağına inanıyordu. Oysa seçimleri kaybetti. Bu ne Venizelos ve Venizelosçuların ne de itilaf güçlerinin beklediği bir yenilgi idi. Venizelos parti başkanı olarak milletvekili bile seçilememişti.

Ünlü Yunanlı tarihçi Y. Th. Mavrogordatos Venizelos'un ve taraftarlarının bu yenilginin gelișini nasıl göremediklerini șu sözlerle açıklar: "Belki hem Venizelos hem de Fileleftheri kendi milliyetçilik tuzaklarına kendileri düşmüştü. Kendi milliyetçilikleri ile körleşen gözleri 'Millet'in 'Büyük Yunanistan'ın' yaratılmasina ve yaratıcısına evet demekten başka bir şey yapacağını düşünmemiş ve bundan başka herşeye gözlerini kapamıștı. Fileleftheri partisinin seçimler öncesi en büyük propoganda aracının Londra'da pahalı bir kă̆ıda basılan 'iki kıta ve beş deniz'de hüküm süren Yunanistan haritası bu durumun en açık kanıtıdır. Bu harita Venizelos karşıtları tarafindan yırtılacaktır." (Mavrogordatos, 2005:225.) Yine Mavrogordatos'tan edindiğimiz bilgilere göre 'Eski Yunanistan'da' 'Küçük Fakat Saygın Yunanistan' fikrini savunan halk Yunanistan'in bu genişlemesine ya ilgisiz kalıyor ya da düşmanca karşılıyor, sokaklarda İzmir ve Batı Trakya'nın Yunanistan'a dahil olması konusunda 'Bu yerleri istemiyoruz' (den tha thelume) sloganları atıyordu.

$\mathrm{Bu}$ seçim sonucunda oy verilmeyen yalnız Venizelos değil Venizelos'un Megali İdea politikası idi. Megali İdea'ya hayır oyu çıkmasında, Venizelos karşıtlarının yanısıra Yunanistan'a henüz katılmış olan 'Yeni Topraklarda' yaşayan ve Yunanlı olmayan nüfusun oyları da elbette önemli bir rol oynamıştır. 1 Kasım 1920 seçimleri Venizelos'un ve Megali İdea'nın Yunanistan sınırları içinde aldığı teorik düzeydeki ilk yenilgi oldu. 1 Kasım1920 seçimlerinin galipleri 'Küçük Fakat Saygın Yunanistan'1 isteyenlerdi. Venizelos 1920 seçiminde yaşadığı hezimet sonrası aktif politikayı bıraktığını duyurarak ülkeden ayrıldı.

Yeni kurulan hükümetin başbakanı Dimitrios Rallis, dıșişleri bakanı ise Gunaris oldu. Daha da önemlisi istifa etmeksizin ülkeden ayrılan Kral Konstantinos Yunanistan'a geri döndü. Durum, Venizelos'un Yunanistanı'nı ve Megali İdea'yı desteklemiş olan batılı ülkeler tarafından endişe ile izleniyordu. Venizelos karşıtı yeni hükümet Balkan Savaşları'ndan başlayarak yaşanan savaşlar ve siyasi gerginlikten bıkan, Yunanistan'ın Büyük Yunanistan (Megali Ellada) olmasını değil de 'Küçük Fakat Saygın Yunanistan'ı olmasını destekleyenlerin oylarını almış olmasına rağmen Küçük Asya'daki Yunan ordusunu geri çekmedi. Büyük bir olasılıkla Megali İdea ve Büyük Yunanistan fikri onların da gözlerini kamaştırmıştı. Üstelik, yeni iktidarın 1921 yılında basına uyguladıkları 
sansür nedeniyle özellikle halk kendileri için yalnızca bir askeri yenilgi değil Felaket ile bitecek dönemin gelişini 'okuyamadı' (Yanulopulos, 1999:290).

Venizelos I. Dünya Savaşı öncesi başlayan Megali İdea'yı romantik bir söylemden çıkarıp olabilirlik safına sokmuştu. Nitekim 15 Mayıs 1919'da Yunan donanması İzmir açıklarında idi. Venizelos tarafından Yunanlılara sunulan Megali İdea ve Büyük Yunanistan haritası bir kez Yunanistan yurttaşları tarafından 1 Kasım 1920 seçimlerinde yenildi. Bu yenilgi o kadar büyük ve beklenmedikti ki Venizelos aktif politikayı bıraktı, Yunanistan'1 terk etti, Paris'e yerleşti. Megali İdea'yı gerçekleştirmeye çalışan Venizelos'un gözden kaçırdığı kaçırdığı en önemli unsur; Mustafa Kemal Atatürk önderliğinde direnişe geçen Türk milli hareketi ise Megali İdea'nın savaş alanında aldığı büyük yenilgiyi getirdi. Tarihin bir ironisi sonucu Venizelos Büyük Yunanistan'ın savaş alanında aldığı yenilgi sırasında hükümetin başında değildi. 1 Kasım 1920 seçimleri bir bakıma Venizelos'u Megali İdea'nın yenilgisinin yükünü taşımaktan kurtarmıştı. 1922 yenilgisi sonrası siyasi hayata müdahale eden ordu temsilcilerinin Lozan'da Yunanistan'ı temsil etmek üzere çağırdıkları kişi Venizelos'du. Lozan Antlaşmasını imzalayan Venizelos hem çağdaş Türkiye Cumhuriyeti'nin doğuşuna hem de Megali İdea'nın yenilgisini, tarih oluşuna bizzat tanıklık ediyordu.

\section{Ic-Lozan'dan Ankara Antlaşmasına Venizelos}

1922 sonrası Yunanistan'da uzun sürecek çalkantılı bir dönem başlayacaktır. Venizelos'un gerçekleştirdiği, Karl ve Venizelos karşıtlarının halkın karşıt görüşlerine rağmen devam ettirdiği Megali İdea'nın savaş alanında sonlanması ile büyük bir karmaşa başladı. Kara ve Deniz Kuvvetleri bir darbe yaptı. ${ }^{22}$ Kral Konstantinos'u ülkeden ayrılmaya zorladı. Yenilginin sorumlularını aradı. Yunanistan'ın savaşı kaybetmesine neden olan 'hainler' bulundu. Venizelos karsit1 ve Kral Konstantin taraftarı olan altı üst düzey siyasi ve askeri görevli ${ }^{23}$ yapılan askeri mahkemeden sonra, ‘vatan hainliği' suçlamasıyla kurşuna dizildi (28 Ekim 1922).

Lozan Antlaşması'nda bir yanda yenik bir ülkeyi tam imza yetkisi ile temsil eden Venizelos bir tarafta ise İsmet İnönü'nün önderliğindeki heyet vardır. Lozan Antlşaması'nda Venizelos'un karşısında bulunan Türk heyeti ise 1922'de yalnızca bir savaş kazanmış bir ülkeyi değil Kurtuluş Savaşını, 'Türk'ün ateşle imtihanını' kazanmış bir heyettir. Venizelos, Türkiye'nin oluşumunu ve Osmanlı İmparatorluğu'ndan farklılığını yani modern bir ulus devlet olma hareketini Lozan sırasında anlamıștır. Bu nedenle özellikle Yunanistan tarafı için alınması çok zor bir kararı alarak 30 Ocak 1923 tarihinde resmi adı ile "Yunan ve Türk Halklarının Mübadelesine İlişkin

\footnotetext{
${ }^{22}$ Darbeyi yapan isimler şöyle Albay Gonatas, Albay Plastiras ve Amiral Fokas.

${ }^{23}$ Bu isimler şöyle: D. Gunari, P. Protopapadaki, G. Baltaci, N. Theotoki, N. Stratu, ve general G. Hacianesti.
} 
Sözleşme ve Protokol" yani Nüfus Mübadelesi'ni imzalamıştır. Megali İdea'yı olabilirlik safına getiren, savaşta aldığı yenilgi sırasında yurtdışında olduğu için Megali İdea'nın aldığı yenilgiden sorumlu tutulmayan ve Türkiye Cumhuriyeti'nin ulus devlet olarak kurulmasını yani Megali İdea'nın tarih olması demek olan Lozan Antlaşmasını imzalama görevi Venizelos'undur.

Lozan Antlaşması imzalandığında Yunanistan'da hala askeri darbe vardır. Bu nedenle Lozan Antlaşması'nın Yunan Meclisi'nde onaylandığına dair bir belge bulmak ya da TBMM'de olduğu gibi aldı ğı eleştirilerin kaydını bulmak imkanı yoktur. ${ }^{24}$ Yunanlı tarihçi Yanulopulos Lozan Antlaşması'nın hem "saygın bir barış" getirdiğini söyler, hem de Küçük Asya savaşının yenilen tarafı için imzalanmış "olabilecek en iyi" antlaşma olarak yorumlar (1999:316).

Lozan Antlaşması sonrası Yunanistan Eleftehrios Venizelos yeniden başbakan seçildiği 1928 seçimlerine kadar büyük sarsıntılara sahne olur: “Anadolu'daki büyük bozgunu takip eden on dört yll zarfinda tam on dokuz hükümet geldi geçti. Ü̧̧ defa rejim değişikliği (1924 Mart'ında Cumhuriyet, 1925 'te General Pangalos Diktatörlüğ̈̈ ve 1935'in Kasım ayında Krallı̆̆ın yeniden ihdast) oldu, yeni askeri ayaklanma ve hükümet darbesi ortaya çıktı -(a)Eylül 1922'de Albay Plastiras ve Gonatas ihtilali (b)Ekim 1923'te General Gargalides ve Leonardopulos'un karșı isyanı (c)Haziran 1925'te General Pangalos'un hükümet darbesi (d)Ağustos 1926'da General Kondilis'in hükümet darbesi (e)6 Mart 1933'te General Plastiras'ın karşı darbesi (f)Mart 1935'te Venizelosçu karşı darbe-. Bunlara askeri cuntaların hükümet işlerine karışmasının doğurduğu sayısız fesat ve fitne hareketlerini de ilave etmek lazımdır. Bütün bu iç problemler yetmiyormus gibi İtalya'nın 1923 A ğustos'unda -31 A ̈̆ustos 1923'te, Yunan-Arnavutluk sinır komisyonu başkanı General Tellini'nin öldürü̈lmesine karşıllk olarak bu meseleden Yunan hükümetini mesul tuttuğu için İtalya Korfu Adası'nı işgal etmişti. 15 milyon liret tazminat ödendikten sonra Ittalyanlar adayı boșalttı.- Korfu adasın işgal edişi ve General Pangalos'un 1926'da Bulgaristan'a yaptığ çılgın saldırt gibi dış karışıklıklar da vardı." (Pallis, 1995:96). Bu süreç içinde Venizelos Milli Bölünme'nin Yunanistan'a verdiği zararı ve Yunanistan'ın içinde bulunduğu zor koşullara (ekonomik iflas, yerleştirilmesi gereken göçmenler ve ülkenin yeniden yapılanması gerekliliği) yakından tanıklık etmiştir.

Yunanlı tarihçiler 19 Ağustos 1928 seçimleri ile tekrar göreve gelen Venizelos'un 1922 sonrası iç politikada da daha uzlaşmacı bir tavır sergilediği konusunda hem fikirdirler. Venizelos İtalya' da Mussolini'nin

\footnotetext{
${ }^{24} \mathrm{Bu}$ süreç içinde Yunanistan'da Lozan Antlaşmasını eleştiren iki isim vardır bunlardan biri Theodoros Pangalos diğeri ise Yoannis Metaksas'dır. Bu her iki isim de darbe yapmıs (Pangalos 1926'da, Metaksas ise 1936-1940), kendilerini Yunanistan'1 yönetecek darbe lideri konumuna yükseltmiştir. Bu darbe dönemleri ve liderleri Yunanistan'da bazı küçük marijinal çevreler hariç olumsuz hatırlanmaktadır.
} 
yükselen faşist hareketinin, Yunanistan'ın ekonomik olarak içinde bulunduğu darboğazın, romantik milliyetçi söylemin Yunanistan'1 içine soktuğu olumsuz koşulların ve yaklaşan büyük ekonomik krizin, bölgede Osmanlı İmparatorluğu yerine çağdaş Türkiye'nin kurulduğunun (bk. EKII) ve Yunanistan'ın artık bir ulus devletle karşıkarşıya olduğunun farkındadır. Bütün bu deneyimleri hem iç hem de dış politikada daha uzlaşmacı bir çizgi izlemesine sebep olur. I. Dünya Savaşı öncesi Megali İdea'nın en ateşli savunucusu, 19 Ağustos 1928 seçimlerini kazandıktan yalnızca onbir gün sonra İsmet İnönü'ye hitaben yazdığı mektupla Türkiye ile Yunanistan arasında daha büyük ve kapsamlı bir barıșın yapılacağı 30 Ekim 1930 Ankara Antlaşması'nın zeminini hazırlayacaktır.

\section{Kaynakça}

Babinyotis, G. 1998. To Leksiko tis Neas Ellinikis Glossas, Kentro Leksilogias, Athens.

Clogg, R. 1997. Modern Yunanistan Tarihi, (Çev. Dilek Şendil), İletişim Yayınları, İstanbul.

Dimaras, K.Th. 1982. Ellinikos Romantismos, Ermis Yayınevi, Athina.

Pallis A. A. Yunanlılar'ın Anadolu Macerası (1915-1922), (Çev. Orhan Azizoğlu), Yapı Kredi Yayınları, İstanbul:1994.

Svoronos, N. 1998. Çăgdaş Hellen Tarihine Bakış, (Çev. Panayot Abacı), Belge Yayınları, İstanbul.

Tsitselikis, K. 2005. “1923’ten Önce Yunanistan'da Müslüman Cemaatler Yasal Süreklilikler ve İdeolojik Tutarsızlıklar”, (Derleyen: Pekin, M.,) 2005Yeniden Kurulan Yaşamlar, 1923 Türk-Yunan Zorunlu Nüfus Mübadelesi, İstanbul Bilgi Üniversitesi Yayınları, İstanbul.

Hacıvasiliu, E. 2005. "I Epiloges stin Eksoteriki Politiki", O Eleftherios Venizelos kai i Epohi Tou, Ellinika Grammata, Atina.

Mavrogordatos, G. 2005. "I Ekloges tis 1is Noemvriu 1920" (Derleyen: Veremis, Th. ve Nikolalopoulos, İ.) O Eleftherios Venizelos kai $i$ Epohi Tou, Ellinika Grammata, Atina.

Yanulopulos, N. G., 1999. H Evgenis Mas Tiflosis, Vivliorama, Atina.

Haritalar

Haritaları Veremis, Th. ve Nikolalopoulos, İ.'nın 2005 yılında basılan $O$ Eleftherios Venizelos kai i Epohi Tou (Ellinika Grammata, Atina) adlı kitabın 129. ve 226. sayfalarından aldım. Üzerlerindeki yer isimlerini teknik imkanların elverdiği ölçüde ve okuyucunun anlamasına izin verecek şekilde Türkçeleştirdim. 
EKI: Dönemin mizah dergisi Akbaba 13 Ocak (İkinci Kanun) 1930 yayınladığı bu karikatürle Venizelos'un politikasındaki yeni açılımları ve geçmişindeki Megali İdea'yı resmediyor.
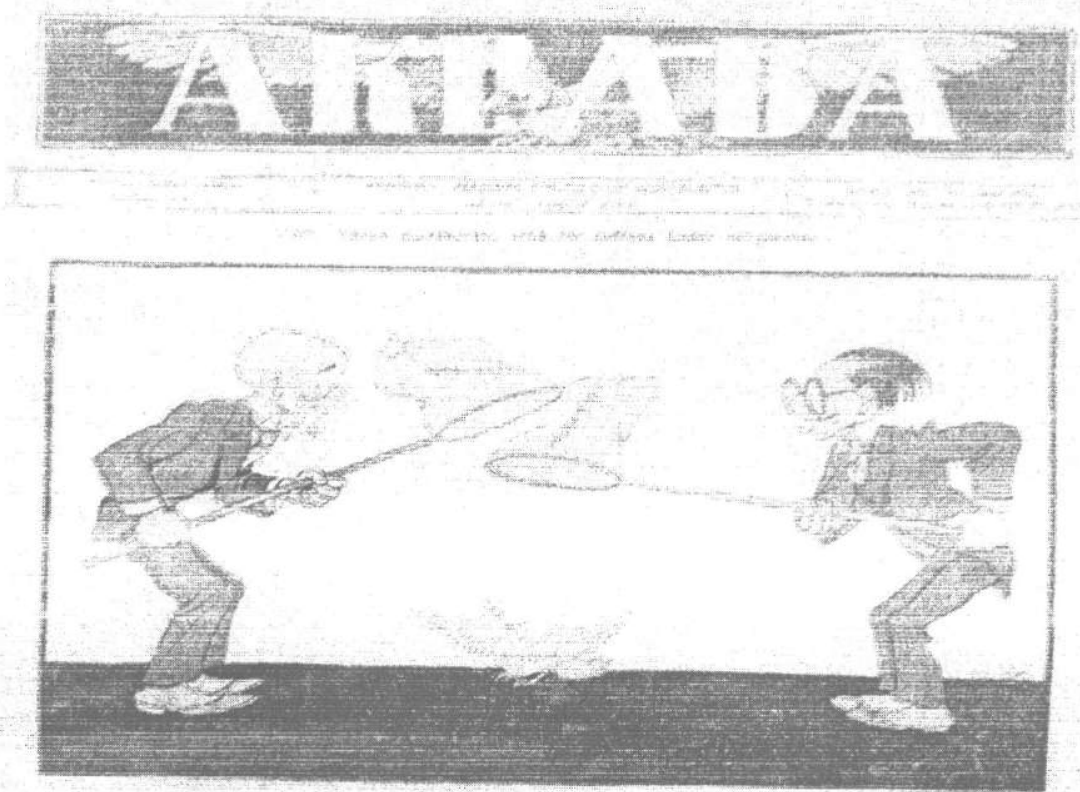

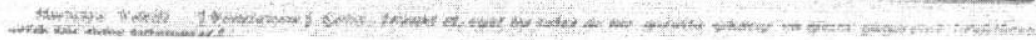




\section{EKII: Venizelos'un elyazısı mektubunun örneği}
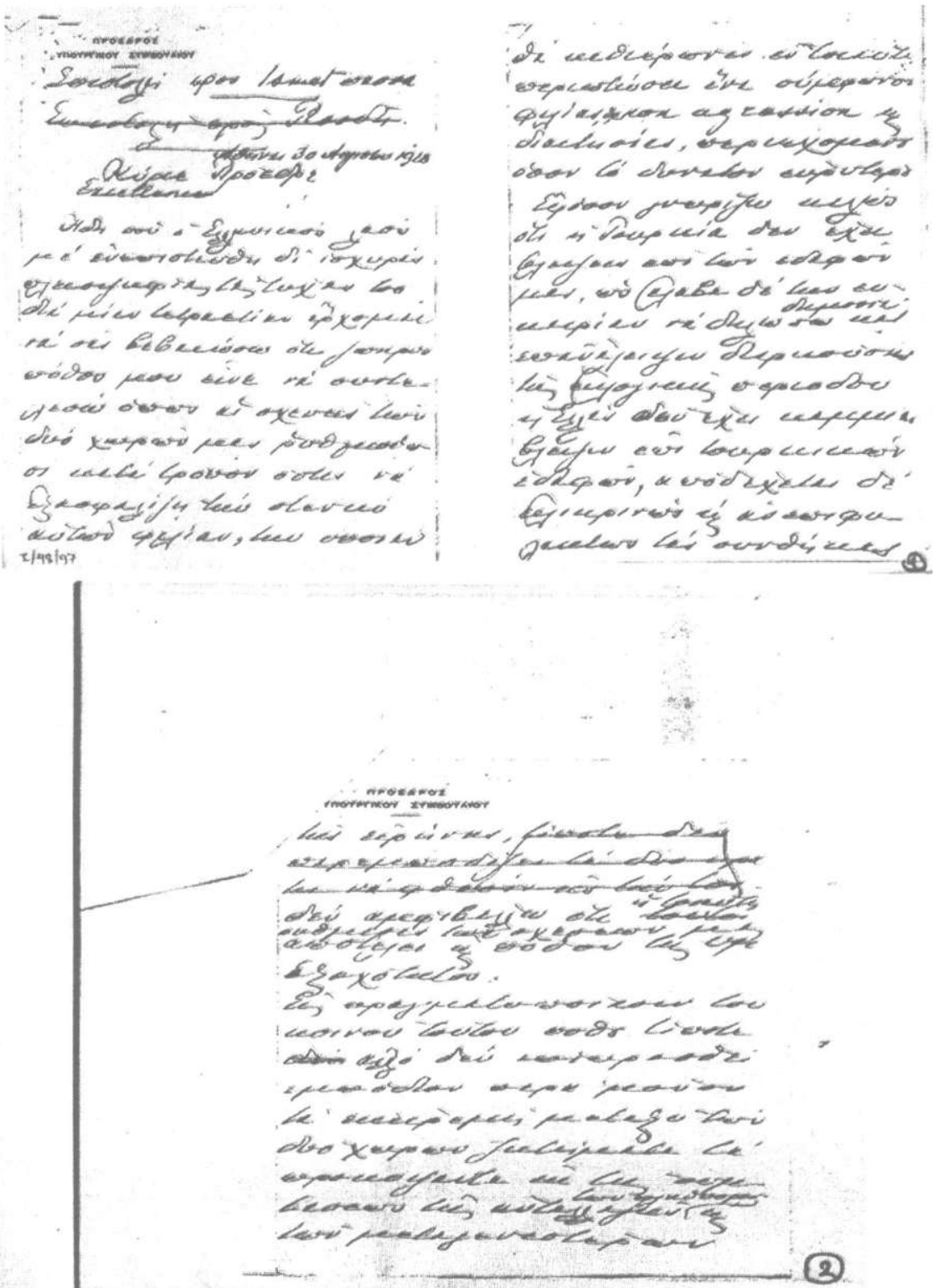


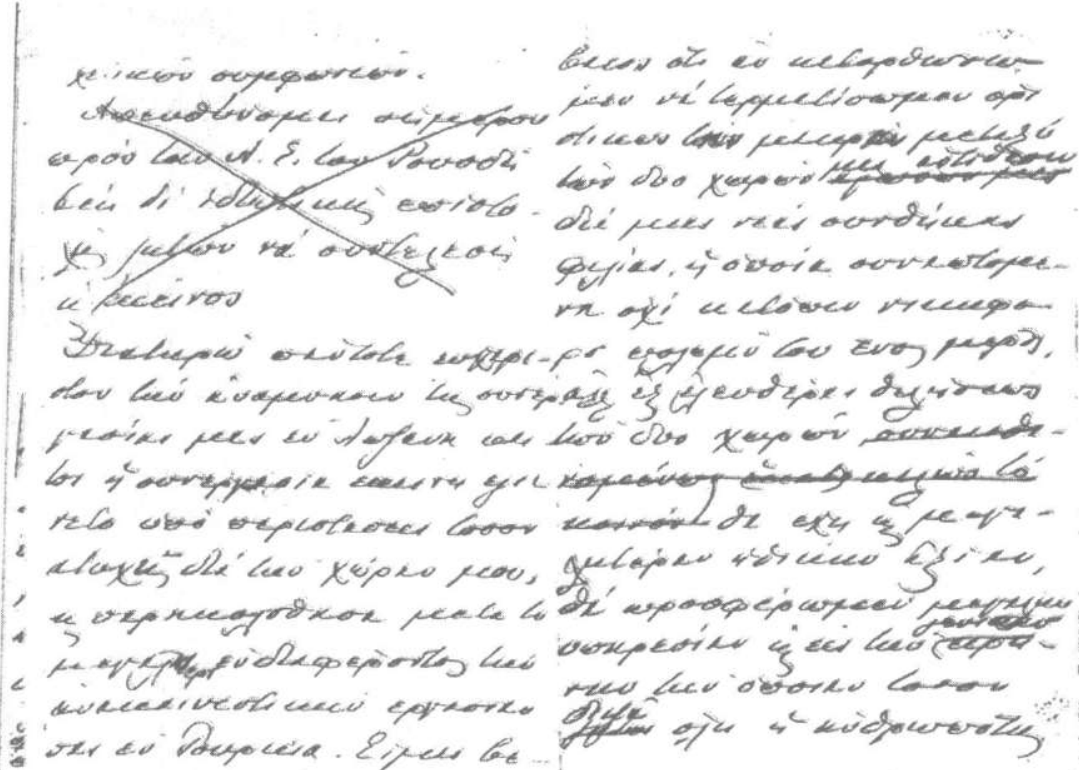


EKIII: Eleftheriọs Venizelos'un Türkiye'nin kurucusu M. Kemal Atatürk’ü Nobel Barış Ödülü'ne aday gösteridği mektubun Türkçe'ye çevirisi. ${ }^{25}$

Yedi yüzyıldır Yakın Doğu ve Orta Avrupa'nın büyük bir kısmı kanlt savaşlara sahne oluyordu. Bu durumun asıl sebebi Osmanlı İmparatorluğu ve Sultanlarin mutlakiyeti idi..

Hıristiyan halkların boyundurluk altına alınmıs olmasının sonucu olarak Haç'ın Hilal'e karşı verdiği savaşlar, bu halkların [Haç'a inanan] arka arkaya yaptı̆̆ı ayaklanmalar boyundurluktan kurtulmayı amaçlıyordu. Bu durum, Sultanların Osmanll Imparatorluğuna vurduğu mühür var oldukça sürekli bir tehlike kaynağı olmaya devam ediyordu.

Mustafa Kemal Paşa milli hareketinin her hasımını yenmesi ve 1922 yılında Türkiye Cumhuriyeti'nin kurulması ile, var olan istikrarsızlık ve fanatizm tarihe karıștı. Gerçekten de çok kısa bir zaman içinde bir milletin hayatında çok büyük ve köklü bir değișiklik yaşandı. Teokratik bir rejim altında yaşayan, şeri düzen ile hukukun sürekli birbirine karıştığ yıpranmış bir Imparatorluğun yerine güç ve hayat dolu milli ve çağdaş bir devlet kuruldu. (...)

Kanlı savaşlarımız nedeniyle yüzyıllar boyunca Türkiye ile sürekli mücadele halinde olan biz Yunanlılar, Eski Osmanll İmparatoluğu'nun ardıll olan ülkede gerçekleşen bu derin değişikliğin sonuçlarınii ilk hissedenler olma şansına sahip olduk. Ona büyük bir samimiyetle elimizi uzattık, o da [bu eli] kabul etti. Çünkü Küçük Asya Felaketi'nden hemen sonra savaştan milli bir devlet olarak yeniden doğmuş olan Türkiye ile yeni bir anlaşma zemini bulacağımızı anladık. (...)

1930 yılında Yunan hükümetinin başı olarak, Türk-Yunan Dostluk Antlaşması'nın Yakın Doğu'da yepyeni bir dönem başlattı̆̆ şu anda, Mustafa Kemal Paşa'yı Nobel Barış Ödülü'ne aday gösterme şerefine nail oluyorum. (...)

${ }^{25} \mathrm{Ne}$ yazık ki bu mektubun orijinal elyazmasının bir fotokopisine sahip değilim. Mektubun Yunanca metnini Yunanlı tarihçi Evanthis Hacıvasiliu'nun $O$ Eleftherios Venizelos kai h Epohi Tou, dlı kitapta yazdığı "I Epiloges stin Eksoteriki Politiki”adlı yazıdan aldim (s.323) 


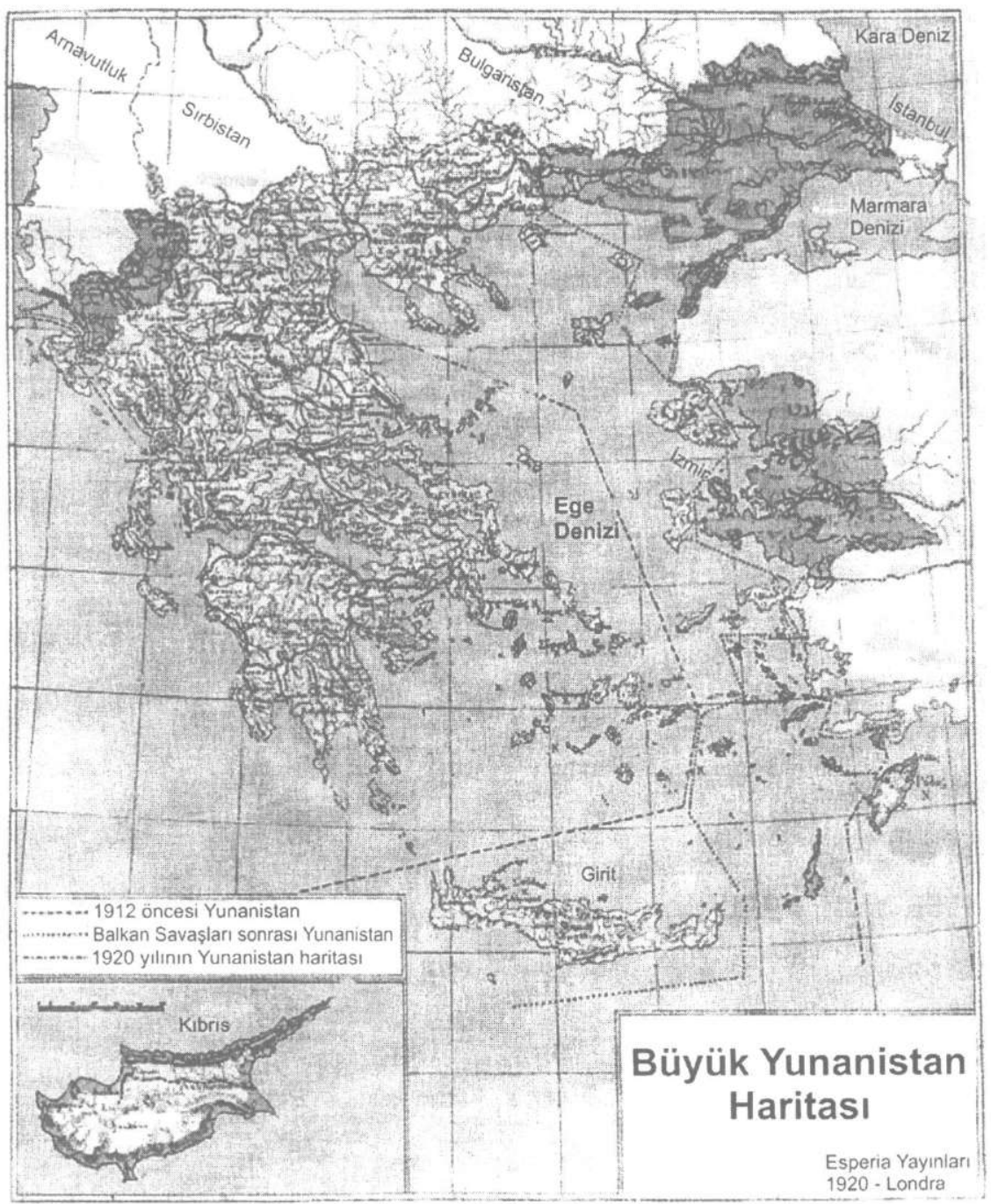




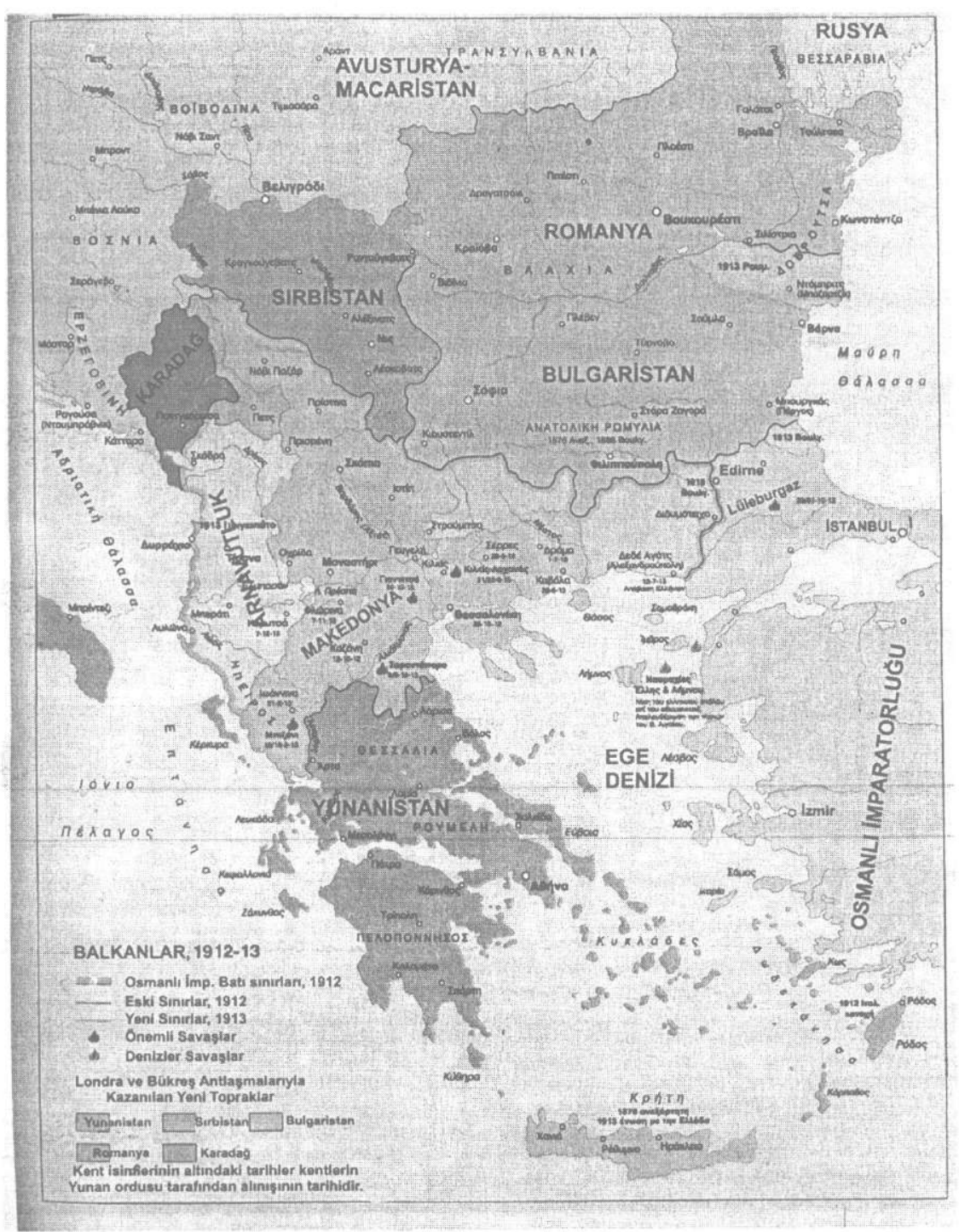

